\title{
EFEITO DA VARIAÇÃO SAZONAL NA PRODUÇÃO DE COMPOSTOS ATIVOS EM Tithonia diversifolia (HEMSL) GRAY, UTILIZANDO ENSAIO COM MICRORGANISMOS
}

PAUla CAROLINA DE SIMONI CORDEIRO E SILVA

Dissertação apresentada à Escola Superior de Agricultura "Luiz de Queiroz", da Universidade de São Paulo, para obtenção do título de Mestre em Ciências. Área de Concentração: Fisiologia e Bioquímica de Plantas.

PIR A C ICABA

Estado de São Paulo - Brasil

Junho - 2004 


\title{
EFEITO DA VARIAÇÃO SAZONAL NA PRODUÇÃO DE COMPOSTOS ATIVOS EM Tithonia diversifolia (HEMSL) GRAY, UTILIZANDO ENSAIO COM MICRORGANISMOS
}

\author{
PAUla CAROLINA DE SIMONI CORDEIRO E SILVA \\ Farmacêutica
}

Orientador: Prof. Dr. RICARDO FERRAZ DE OLIVEIRA

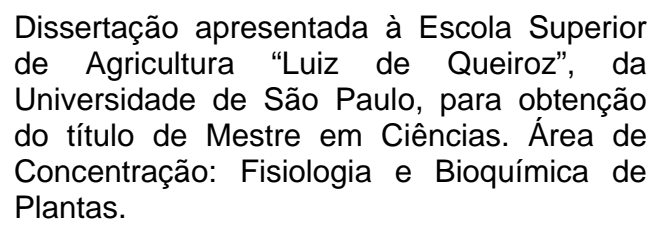

PIR A C I C A B A

Estado de São Paulo - Brasil

Junho - 2004 


\section{Dados Internacionais de Catalogação na Publicação (CIP) DIVISÃO DE BIBLIOTECA E DOCUMENTAÇÃO - ESALQ/USP}

Silva, Paula Carolina de Simoni Cordeiro e

Efeito da variação sazonal na produção de compostos ativos em Tithonia diversifolia (Hemsl), utilizando ensaio com microrganismos / Paula Carolina de Simoni Cordeiro e Silva. - Piracicaba, 2004.

37 p. : il.

Dissertação (mestrado) - - Escola Superior de Agricultura Luiz de Queiroz, 2004.

Bibliografia.

1. Agentes bacterianos 2. Alelopatia 3. Compositae - Variação sazonal 4. Metabólitos secundários I. Título

CDD 583.55 
Agradeço a Deus pela minha vida.

E, aos meus pais Luiz e Wilma, e a meu marido Hélio

Dedico. 


\section{AGRADECIMENTOS}

Ao Prof. Ricardo Ferraz de Oliveira pela orientação, amizade, dedicação e paciência principalmente nos momentos de dificuldade.

Às Profas. Vera Lúcia Rehder e Marta Cristina Teixeira Duarte pela colaboração e pelos tantos conselhos e apoio ao meu trabalho. E à técnica Adriana da Silva Santos pela disponibilidade na realização da CCD.

Ao Prof. Murilo Melo, Prof. Luiz Antonio Gallo e o técnico Amaral pela disponibilização do laboratório e do tempo para a realização das muitas extrações.

Aos colegas "Pequeno" e "Tirolês" pela literal FORÇA na realização do cultivo, coleta e das podas.

Ao prof. Ricardo Kluge pelo empréstimo do dispersor e participação no Exame de Qualificação.

Á profa Patrícia Dias pelos ensinamentos na graduação e participação fiel na pós-graduação.

Aos colegas de departamento Miriam, Mauro, Oscar, Rafael, Marcelo, Gustavo, Camila e Luciana pela amizade e auxílio nos momentos de dúvida e insegurança.

A todos os professores das disciplinas cursadas durante o curso e respectivos técnicos.

A meu marido Hélio pela infinita calma e paciência em todas as horas e pelo freqüente apoio e incentivo nos momentos de incertezas.

A amiga Clariça pelo incentivo inicial na realização desta pós-graduação.

Enfim, a todos que tornaram possível a conclusão desse projeto. 


\section{SUMÁRIO}

Página

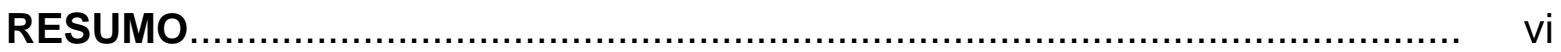

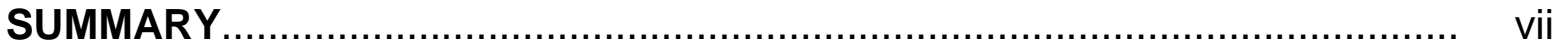

1 INTRODUÇÃO

2 REVISÃO DE LITERATURA ...................................................................... 3

2.1 CARACTERIZAÇÃO BOTÂNICA DA TITHONIA DIVERSIFOLIA GRAY............. 3

2.2 DISTRIBUIÇÃO GEOGRÁFICA E PROPRIEDADE ALELOPÁTICA.................... 3

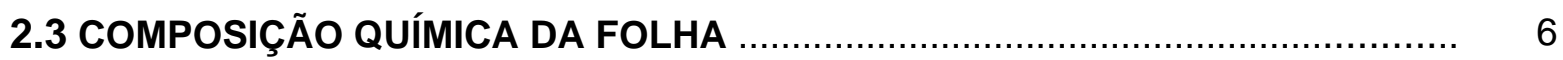

2.4 FITOQUÍMICA .................................................................................. 6

2.4.1 Atividade fagodeterrente........................................................................ 7

2.4.2 Atividades farmacológicas....................................................................

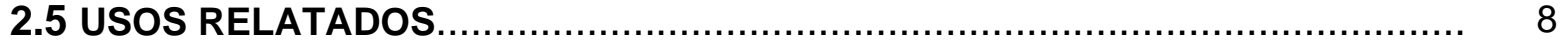

2.5.1 Adubação verde ............................................................................... 9

2.5.2 Complento alimentar para criações............................................................ 10

2.5.3 Atividade antimicrobiana ..................................................................... 11

2.6 INFLUÊNCIA DE ESTRESSES NA PRODUÇÃO DE COMPOSTOS

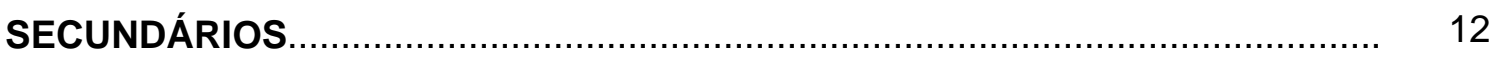

2.6.1 Influência da Variação Sazonal.............................................................. 13

3 MATERIAL E MÉTODOS..................................................................... 15

3.1 OBTENÇÃO DO MATERIAL VEGETAL ……............................................ 15

3.2 METODOLOGIA APLICADA AO ESTUDO FITOQUÍMICO................................. 17

3.2.1 Preparação dos extratos metanólicos de T. diversifolia ................................ 17 
3.2.2 Fracionamento dos extratos metanólicos ................................................ 18

3.2.3 Análise cromatográfica (CCD) dos extratos e frações.................................... 20

3.3 METOdOLOGIA APLICADA AO ESTUdO FISIOLÓGICO................................... 20

3.3.1 Variação sazonal de metabólitos secundários........................................... 20

3.4 METODOLOGIA APLICADA NOS BIOENSAIOS............................................ 20

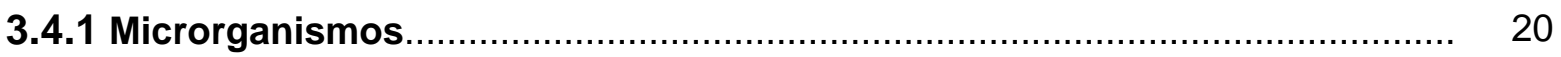

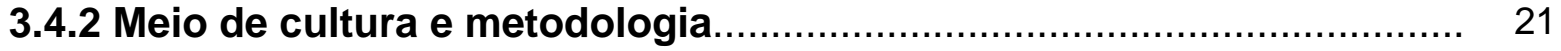

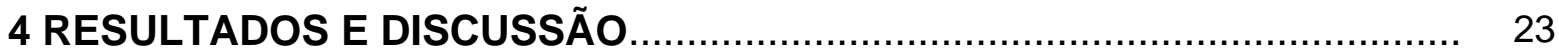

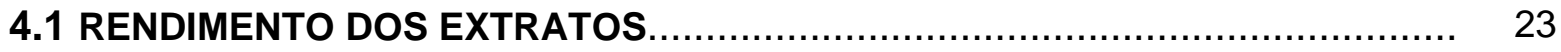

4.2 ANÁLISE DOS EXTRATOS POR CCD................................................. 23

4.3 AVALIAÇÃO DA ATIVIDADE ANTIMICROBIANA ........................................ 25

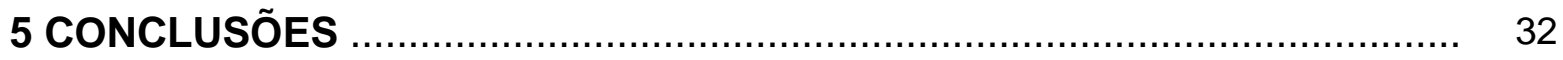

REFERÊNCIAS BIBLIOGÁFICAS.............................................................. 33 


\title{
EFEITO DA VARIAÇÃO SAZONAL NA PRODUÇÃO DE COMPOSTOS ATIVOS EM Tithonia diversifolia (HEMSL) GRAY, UTILIZANDO ENSAIO COM MICRORGANISMOS.
}

\author{
Autora: PAULA CAROLINA DE SIMONI CORDEIRO E SILVA \\ Orientador: Prof. Dr.: RICARDO FERRAZ DE OLIVEIRA
}

\section{RESUMO}

A variação sazonal na produção de compostos secundários em Tithonia diversifolia (Hemsl) Gray foi investigada desde a primavera de 2002 até o inverno de 2003. Coletas bimensais foram realizadas com posterior extração e fracionamento do material vegetal (folhas e flores). As amostras foram monitoradas por CCD e analisadas quanto a atividade antimicrobiana contra Staphylococcus aureus, Escherichia coli, Salmonella choterasuis e Pseudomonas aeruginosa, pelo método de microplaca. Os perfis cromatográficos foral distintos para as diferentes épocas do ano, sendo evidenciada a presença de um grupo de substâncias em maior quantidade no mês de Abril de 2003 (outono), período de pré-florada desta espécie. Os extratos foram ativos para apenas dois microrganismos dentre os quatro testados. Algumas frações apresentaram CIM (concentração inibitória mínima) significativa $(<1 \mathrm{mg} / \mathrm{mL})$. 


\title{
EFFECTS OF SEASONAL VARIATION UPON PRODUCTION OF ACTIVE COMPOUNDS IN TITHONIA DIVERSIFOLIA (HEMSL) GRAY USING MICRORGANISMS BIOASSAY
}

\author{
Author: PAULA CAROLINA DE SIMONI CORDEIRO E SILVA \\ Adviser: Prof. Dr. RICARDO FERRAZ DE OLIVEIRA
}

\section{SUMMARY}

The seasonal variation upon production of active compounds in Tithonia diversifolia (Hemsl) Gray was investigated from spring of 2002 until winter of 2003. Leaf samples were collected every three months for posterior extraction and analysis. The samples were monitored by Thin Layer Chromatography (TLC) and analyzed for anti-microbial activities on Staphylococcus aureus, Escherichia coli, Salmonella choterasuis and Pseudomonas aeruginosa, using micro-plate method. The TLC results showed a clear accumulation of active compounds during April. The extracts were active for only two microorganisms of a total of four studied. 


\section{INTRODUÇÃo}

Tithonia diversifolia é uma planta herbácea pertencente à família Asteraceae, originária da América Central. É encontrada em diversos países da Ásia, África e América do Sul, onde recebe diversos nomes, tais como girassol mexicano, raio de sol, unha de gavião, entre outros.

Nas publicações relacionadas com a utilização geral desta espécie, encontram-se usos agronômicos, como adubação verde para algumas culturas, por exemplo milho e arroz, pois apresenta altas concentrações de fósforo e potássio em sua biomassa; nutricionais, na complementação de rações para gado e aves, principalmente pela presença de xantofilas que intensificam a coloração das gemas dos ovos; e ainda terapêuticos, como fitoterápicas contra diversos males como desinteria amébica, inflamações cutâneas,infecções, hepatite e recentemente contra tumores, como leucemia.

A razão pelas diversas atividades relatadas é a presença de metabólitos secundários, como lactonas sesquiterpênicas e flavonóides. Tais compostos estão presentes nas folhas e hastes deste vegetal. Sendo que diversos tipos de extratos têm sido testados atualmente, contra doenças resistentes aos tratamentos convencionais.

A produção de metabólitos secundários nos vegetais é influenciada por diversos tipos de estresses como temperatura, umidade do solo, contaminantes do ar e do solo, excesso de radiação e variação sazonal, que alteram-na quali e quantitativamente. A variação sazonal engloba alterações bruscas tanto de temperatura quanto no nível de umidade no solo, fatores estes que provocam desvios de rotas biossíntéticas de metabólitos primários e secundários. 
Estudos relacionados com a detecção e monitoramento da influência de tais fatores são raros, apesar de fundamentais para espécies medicinais, principalmente.

Frente a escassez de parâmetros analíticos relativos a variação na produção de compostos ativos dessa espécie ao longo do ano, vêem-se necessárias a elucidação e a padronização de tais medidas.

Para isso, uma das ferramentas utilizadas é o ensaio microbiológico, que além de confirmar a atividade antibacteriana, ainda permite detectar a variação sazonal na produção dos metabólitos ativos. Dentre as espécies de microrganismos mais utilizados para bioensaios foram escolhidos quatro de maior importância Staphylococcus aureus, Escherichia coli, Salmonella choterasuis e Pseudomonas aeruginosa

O objetivo desse trabalho é estudar os possíveis efeitos da variação sazonal sobre a produção de compostos ativos de Tithonia diversifolia (Hemsl) Gray, a partir de extratos obtidos a partir da parte aérea da mesma. E, utilizando ensaios microbiológicos obter a CIM (concentração inibitória mínima) dos extratos para cada microrganismo em cada estação do ano, para assim, estabelecer a época ideal da colheita e processamento dessa espécie visando um maior aproveitamento da biomassa vegetal rica em compostos secundários. 


\section{REVISÃO DE LITERATURA}

\subsection{Caracterização Botânica da Tithonia diversifolia Gray}

A Tithonia diversifolia pertence à Divisão: Sphermatophyta, Classe: Dicotiledoneae, Subclasse: Metaclamídeas, Ordem: Campanuladas, Família : Asteraceae, Gênero: Tithonia e Espécie: Tithonia diversifolia (Hemsl.) Gray

Os nomes vulgares são: Margaridão amarelo, Unha de Gavião, Girassol silvestre, Girassol mexicano, Botón de oro, Rayo de sol, Mirasol, Botão de Ouro, Arnica da Terra e Quil Amargo.

\subsection{Distribuição Geográfica e Propriedade Alelopática}

O gênero Tithonia compreende dez espécies, todas originárias principalmente do México. Uma delas a Tithonia diversifolia Gray é um arbusto, que foi anteriormente identificado como $T$. rotundifolia ou $T$. tagetiflora. Foi introduzida no Sri Lanka e em partes da Índia como uma planta ornamental, mas posteriormente cresceu de forma silvestre. Na Nigéria, a planta ocorre à margem das estradas e em terras não cultivadas, e também como um invasor de campos de cultivo na zona de transição entre a floresta e a savana. Atualmente está distribuída em toda parte dos trópicos úmido e subúmido na América Central e do Sul, Ásia e África (Katto et al., 1995; Akinola et al. 2000; Jama et al.2000). 
A planta cresce de 1,5 a $5,3 \mathrm{~m}$ da altura; os ramos crescem profusamente, e produzem diversas folhas simples alternadas, pecioladas, e em sua maioria com 7,0 a $20 \mathrm{~cm}$ de comprimento e, com 4,0 a $20 \mathrm{~cm}$ de largura (Figura 1-A). Com três a cinco lóbulos cuneados até subtruncarem na base a maioria decorrente na base do pecíolo, bordas serradas e pedúnculos fortes de 5 a $20 \mathrm{~cm}$ de comprimento; 12 a 14 flores amarelo brilhante ou alaranjadas de 3,0 a 6,0 cm de extensão (Figura 1-B). Se estabelece naturalmente a partir da semente, e seu período pode ser anual, bianual ou perene, dependendo do habitat (Katto et al., 1995; Akinola et al., 2000).

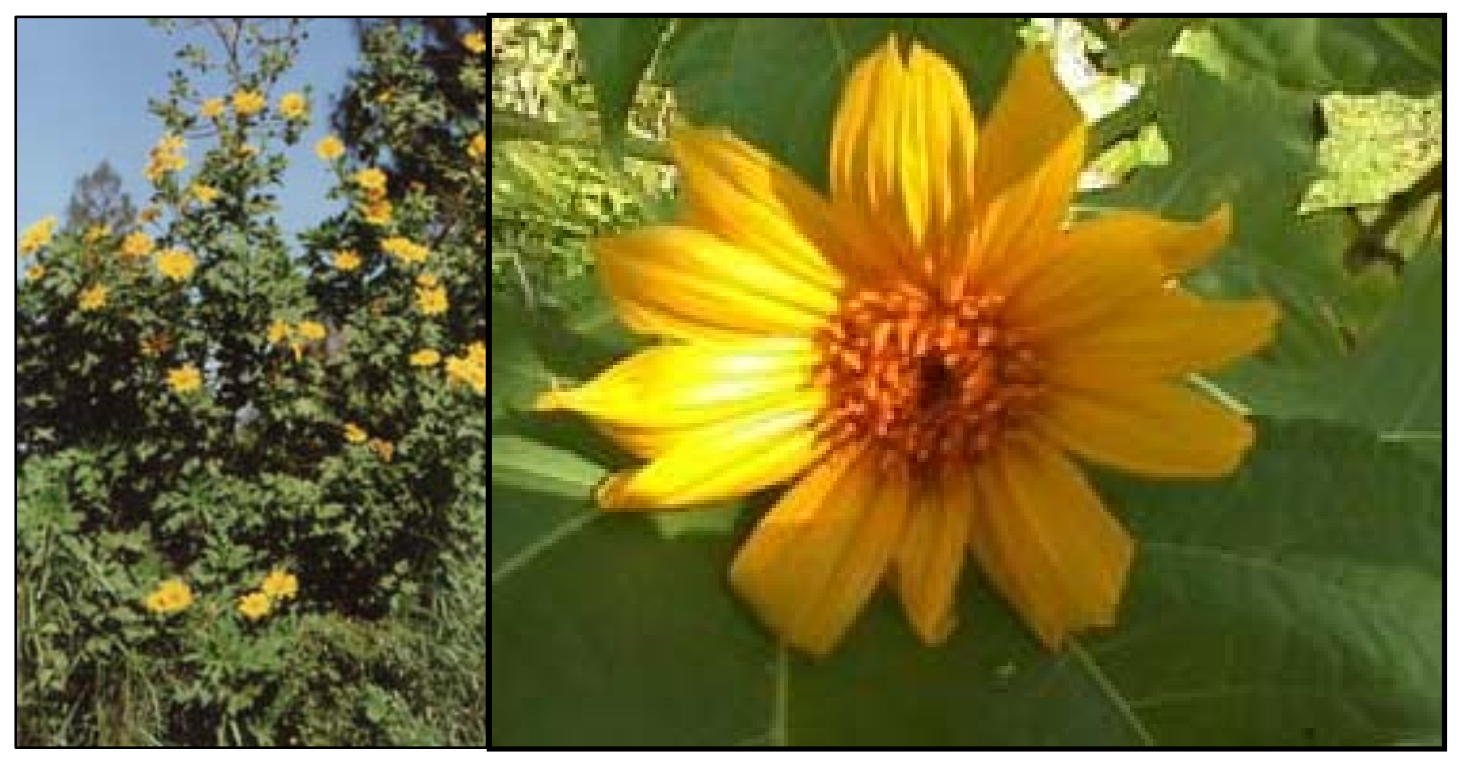

Figura 1 - (A) Arbusto da Tithonia diversifolia. (B) Detalhe da flor

Para a produção de forragem, entretanto, a germinação e emergência são inadequadas. Isso sugere a existência de uma dormência da semente. Tratamentos feitos com água quente a $80^{\circ}$ até $100^{\circ} \mathrm{C}$, calor seco a $80^{\circ} \mathrm{C}$ e imersão em solução de ácido concentrado ou peróxido de hidrogênio, aumentaram a germinação das sementes. No entanto, a imersão das mesmas em água quente por 11 a 15 minutos, ou em calor seco por 20 minutos pode 
resultar em mais de $65 \%$ de germinação. Estes métodos são recomendados para serem usados nas sementes de Tithonia diversifolia. (Akinola, 1999).

$\mathrm{Na}$ Ásia, tornou-se uma planta predominante em algumas regiões onde estava presente. Isto sugere que essa planta tenha uma forte habilidade competitiva e possível atividade alelopática contra outras espécies. O girassol mexicano foi relatado como contendo lactonas sesquiterpênicas, i.e. targinina A, targinina C, e flavonóide hispidulina. Essas substâncias reduzem a germinação da semente e o crescimento da muda de algumas plantas testadas. Contudo, os compostos isolados da flor do girassol mexicano são conhecidos como inibidores do crescimento de plantas (Tongma et al., 1998).

Extratos metanólicos das folhas de Tithonia diversifolia contendo tagitinina C, tagitinina A e flavonóide hispidulina, inibiram a germinação e o crescimento das sementes testadas. (Baruah, 1994). Extratos aquosos desta planta inteira também inibiram a germinação e o crescimento das sementes testadas (Tongma, 1997).

Tongma et al. (1998) testaram a alelopatia desta espécie plantando sementes de outras espécies em solo previamente plantado com a $T$. diversifolia. Houve inibição do crescimento da raiz e da parte aérea de tais espécies testadas.

Tongma et al. (2001) comprovaram que a atividade alelopática de extratos aquosos de $T$. diversifolia cultivada em solo com baixos níveis de umidade, foi maior quando comparada àquelas cultivadas em solo com altos níveis de umidade. Concluíram também que quando cultivadas com pouca umidade no solo, seu acúmulo de biomassa é reduzido, embora aumente a produção de substâncias alelopáticas por peso seco, quando comparado àquela cultivada em solo úmido. O estresse hídrico não só afetou diretamente o crescimento da planta, mas também aumentou a produção de compostos alelopáticos pela mesma.

Em condições de estresse hídrico houve redução do peso seco, da altura e área foliar, e maior atividade fitotóxica nas plantas fixadas em solo com 
menor nível de umidade. A concentração de aleloquímicos foi maior nas plantas submetidas ao estresse hídrico. (Tongma, 2001).

Em condições de campo, durante as estações do ano há variação na precipitação de chuvas, sendo que na estação seca, a planta é acometida pela escassez de água no solo. É nessa época que o nível de umidade do solo atinge cerca de $20 \%$ ou menos, submetendo o vegetal a uma situação de estresse hídrico. Assim, a produção de compostos alelopáticos é aumentada consideravelmente (Tongma, 2001).

\subsection{Composição química da folha}

A análise da composição química do pó da folha da Tithonia diversifolia em porcentagem é: Umidade $11.88 \%$, Proteína crua $22.07 \%$, Extrato etéreo 8.12\%, Fibra crua 6.74\%, Cinza 12.47\%, Carboidratos (por diferença) 38.72\%, Cálcio ${ }^{1}$ 390.60, Fósforo ${ }^{1} 444.85$, Vitamina A $^{1}$ 0.299, Taninos $^{1}$ 83.33, Carotenos ${ }^{2}$ 130.94, Xantofilas ${ }^{2} 333.93$, Xantofilas hidroxiladas ${ }^{2} 161.60$. ((1): $\mathrm{mg} / 100 \mathrm{~g}$ de pó; (2) $\mu \mathrm{g} / 100 \mathrm{~g}$ de pó) (Medina et al., 1999).

\subsection{Fitoquímica}

Com relação à química de micromoléculas, algumas espécies da família Asteraceae possuem como característica a presença de terpenóides, poliacetilenos e flavonóides (Bohlmann, 1990; Heywood et al., 1977), sendo que dentre os terpenóides destacam-se as lactonas sesquiterpênicas (LSTs) com importância quimiotaxonômica (Seamam, 1982) e por apresentarem diversas atividades biológicas (Rodriguez et al., 1976; Picman, 1986).

As LSTs são metabólitos secundários provenientes da via do mevalonato, são incolores, amargas, relativamente estáveis, constituintes lipofílicos derivados biogeneticamente do trans-trans farnesil-pirofosfato e sofrem ciclização e subsequente modificações oxidativas, possuindo uma 
grande variedade de esqueletos carbocíclicos conhecidos, tais como: germacrolídeos, eudesmanolídeo, heliangolídeo, furanoeliangolídeo e guaianolideo dentre outros menos comuns (Seaman, 1982, Rodriguez, 1976).

As LSTs também podem ter papel de defesa na planta, atuando contra diversos herbívoros e inibindo o crescimento de larvas de diversas espécies. Outra atividade atribuída às LSTs é a de alelopatia, ou seja, algumas espécies utilizam LSTs para afetar a germinação e o crescimento de outras espécies vegetais (Macías et al.,1992). Segundo Baruah e colaboradores (1994), algumas LSTs que atuam desta forma sobre arroz, sorgo e rabanete, são tagitinina A e tagitinina C.

De acordo com Dutta e colaboradores (1986), vários estudos indicam que produtos naturais de plantas são excelentes fagodeterrentes para diversas espécies de insetos. Dentre esses produtos existem poucas plantas contendo lactonas sesquiterpênicas com essa atividade, como por exemplo a lactona sesquiterpênica glaucolídeo-A isolada da Vernonia sp. reduz a alimentação das larvas de seis espécies de lepdópteros. Tais derivados de planta com atividade repelente de insetos é interessante devido ao baixo nível de risco apresentado para organismos não-alvo.

\subsubsection{Atividade fagodeterrente}

Essa atividade fagodeterrente foi encontrada também para a $T$. diversifolia em experimentos com larvas de Philosamia ricini Hutt. Concluiu-se que os compostos presentes na parte aérea desta espécie como tagitinina A e $\mathrm{C}$ e hispidulina inibiram o consumo pelas larvas. Os tratamentos contendo esses compostos tiveram menor área foliar consumida, onde esta inibição aumentou consideravelmente com o aumento da concentração (Dutta et al., 1986).

\subsubsection{Atividades farmacológicas}


Dentre as diversas atividades biológicas apresentadas pelas LSTs, podemos citar ainda, as atividades anti-tumorais, citotóxicas, anti-bacteriana e outras. A diversifolina, produzida pela Tithonia diversifolia, apresentou atividade antiinflamatória, porém seguindo um mecanismo diferente dos convencionais (ex. indometacina) (Rüngeler, 1998; Owoyele, 2003).

Extratos etanólicos desta espécie foram testados quanto a atividade antibacteriana frente a alguns microrganismos como Staphylococcus aureus, Escherichia coli entre outros. Os testes foram positivos para S. aureus sendo

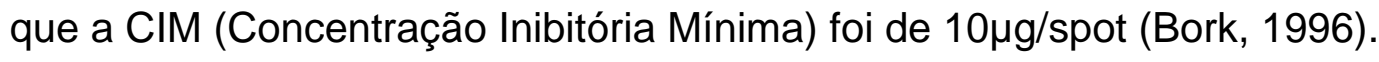

Rüngeler e colaboradores (1998), comprovaram a atividade antinflamatória de substâncias isoladas das folhas do girassol mexicano (diversifolina, tirotundina). Principalmente para diversifolina, que apresentou um novo mecanismo de ação para essa atividade, baseado na inibição do fator de transcrição NF-kB. Esse fator é um mediador central da resposta imune humana responsável pela regulação da transcrição de várias citocinas inflamatórias, imunoreceptores, da enzima cicloxigenase-Il e também de moléculas das células de adesão. Várias condições inflamatórias, como infecções virais ou bacterianas e até citocinas inflamatórias, rapidamente induzem a atividade do Fator NF-kB.

As lactonas sesquitepênicas (germacrolídeos) como a diversifolina reduzem o grau de inflamação devido a inibição da ativação do fator NF-kB, pois, possuem dois sítios eletrofílicos capazes de reagir efetivamente com o fator, impedindo sua ligação ao DNA (Rüngeler, 1998).

Alguns estudos revelaram que o grupo responsável pela maioria das atividades biológicas envolvendo LSTs é o grupo $\alpha$-metileno- $\gamma$-lactona, e a saturação ou adição ao grupo metileno é o responsável pela perda dessas atividades biológicas. Por outro lado, outras substituições na cadeia carbocíclica podem potencializar tais atividades ou inibí-las. Mudanças tais 
como um grupo epóxido ou um éster adicional conjugado podem aumentar a citotoxicidade das LSTs (Picman, 1986).

\subsection{Usos relatados}

Os usos apresentados da Tithonia diversifolia incluem forragem, alimentação de aves domésticas, madeira combustível, adubo composto, demarcação de terra, controle da erosão do solo e material para construção de abrigo para aves domésticas. É especialmente recomendada para a apicultura, pois produz néctar e pólen, e por servir como barreira contra o vento no apiário. Extratos feitos com partes da planta mostraram proteção da colheita contra cupins e como controle de insetos. E também apresentam valor medicinal no tratamento de hepatites, de eczemas e inflamações na pele de animais domésticos e no controle da desinteria amébica. Recentemente descobriu-se um composto antimalárico nas hastes da Tithonia diversifolia (Bordoloi et al., 1995; Katto et al., 1995; Jama et al., 2000).

Para justificar o uso da T. diversifolia pela medicina tradicional do Congo, Tona e colaboradores $(1998,1999)$ testaram entre outros, extratos aquosos das folhas desta espécie contra Entamoeba histolytica, causadora de distúrbios gastrointestinais (diarréias) presentes na amebíase. Os extratos foram ativos contra o parasita com CIM de $62,5 \mu \mathrm{g} \mathrm{mL}^{-1}$, apresentando ainda atividade antiespasmódica em porcos da guiné.

\subsubsection{Adubação verde}

Estudos nas montanhas do oeste do Kenya, na Ásia, no sul e no leste da África identificaram a biomassa verde da tithonia como sendo uma efetiva fonte de fósforo e nitrogênio para o arroz e o milho. Os ramos fixam nutrientes em solos com erosão. Sendo usada para melhoria da fertilidade do solo, incluindo 
geralmente, ambos talos verdes macios e folhas, porém, não talos lenhosos (Jama et al., 2000).

No sudeste da Nigéria, a Tithonia diversifolia é usada como pastagem por bodes, ovelhas e gados nômades ou habitantes de aldeias. Fazendeiros fornecem a forragem para esses animais com o mesmo sucesso tal qual com coelhos. A aceitação pelos gados ruminantes e não-ruminantes, e a abundância da planta na região, são indicativos do seu potencial como uma fonte de alimento não convencional (Katto et al., 1995; Akinola et al., 2000).

\subsubsection{Complemento alimentar para criações}

Profissionais relacionados com a ciência e tecnologia de alimentos têm se dedicado à busca de matéria-prima vegetal que possa ser incorporada na formulação de rações alimentícias das aves de granja, como boa fonte de pigmento (xantofilas), rica em proteína, com baixo conteúdo de fibras e desprovidas de fatores antinutricionais. A análise conduzida para avaliar as folhas da Tithonia diversifolia como uma fonte econômica em potencial de xantofilas para alimentação comercial de aves domésticas demonstrou que esta é uma espécie que se enquadra nos requisitos, principalmente pela presença de xantofilas dihidroxiladas na proporção de 48,33\% (Medina et al., 1999).

As refeições com folhas de Tithonia são suplemento de alto valor nutricional na dieta de galinhas poedeiras e um significado econômico na melhoria da coloração da gema dos ovos, já que são ricas em xantofilas. As xantofilas são responsáveis pela cor das gemas dos ovos, daí sua aplicação em dietas para galinhas poedeiras (Medina et al., 1999; Akinola et al., 2000).

Odunsi e colaboradores realizaram um experimento com galinhas poedeiras com duas dietas: a primeira com uma mistura comercial para poedeiras (MCP) e outra com uma refeição contendo folhas de Tithonia diversifolia (RFT) nas proporções $0,5,10,15$ e 20\%. O tratamento com as duas dietas durou 12 semanas. Os autores concluíram que a produção de ovos foi 
mantida em todas as dietas. O consumo de alimento esteve em torno de $96,27 \mathrm{~g}$ nas galinhas alimentadas com 20\% de RFT e de 106,86g para aquelas com a MCP. A proporção de conversão alimentar em termos de Kg por dúzia de ovos foi maior para as galinhas que receberam a alimentação com 15\% de RFT, enquanto que a MCP teve o maior gasto de comida consumida por dúzia de ovos. Todas as dietas apresentaram um ganho de peso corporal. A unidade Haugh, indicação da gema, a espessura da casca e o peso do ovo não foram influenciados significantemente pela dieta. A cor da gema aumentou $(<0,05)$ na dieta com RFT (em todos os níveis) acima do padrão. Não houve mortalidade durante as 12 semanas do experimento.

Em um estudo feito com coelhos e bovinos, aos quais foi administrada a forragem de Tithonia diversifolia por vários dias, não se observou manifestações de intoxicação. Porém o nível de intoxicação pode ser baixo, ainda que não se descarte a possibilidade de níveis acumulativos pelo consumo por várias semanas (Katto,1995).

\subsubsection{Atividade antimicrobiana}

A população de países como Congo, México e Nigéria utilizam preparações tradicionais de plantas medicinais para o tratamento de diversas doenças infecciosas, entre elas diarréia e infecções cutâneas (Bork, 1996).

Extratos de folhas de $T$. diversifolia são amplamente empregadas para tratar tais doenças, que nestas regiões menos desenvolvidas são consideradas como maiores causas de mortalidade e morbidade infantil, bem como de adultos (Tona et al., 1999).

Testes microbiológicos com extratos aquosos de folhas de $T$. diversifolia para diversas espécies de microrganismos foram realizados por Tona e colaboradores (1999). Tais extratos se apresentaram ativos para Escherichia coli, Salmonela enteritidis, Pseudomonas aeruginosa e Staphylococcus aureus, com CIM $<100 \mu \mathrm{g} \mathrm{mL}{ }^{-1}$. A atividade antibacteriana foi comprovada 
principalmente contra Staphylococcus aureus, apresentando um CIM $<100 \mu \mathrm{g}$ $\mathrm{mL}^{-1}$, do extrato aquoso, o qual inibiu o crescimento bacteriano (Tona et al., 1999).

\subsection{Influência de Estresses na Produção de Compostos Secundários}

Em geral os estresses levam a um estresse oxidativo, reduzindo a fotossíntese, bem como a dissipação de energia, induzindo assim a liberação de formas ativas de oxigênio (Azcon-Bieto, 1996).

Wallaart et al. (1999) concluíram, a partir da aplicação de uma situação de estresse (resfriamento noturno - geada) em Artemisia annua, (Asteraceae), que este fenômeno é o responsável pelo aumento na formação do metabólito artemisinina. A conversão do ácido dihidroartemísico em artemisinina está relacionada com a proteção contra formas ativas de oxigênio formadas durante o período de estresse, sendo esta última a substância final estável da captação de tais agentes prejudiciais ao vegetal.

Experimentos com a espécie Betula pendula demonstraram que o aumento da concentração de $\mathrm{CO}_{2}$ implicou numa maior produção de taninos condensados, bem como de glicosídeos flavonóis nas folhas. Entretanto, o aumento da temperatura reduziu a concentração de compostos fenólicos, embora tenha aumentado a concentração de flavonas agliconas nas folhas. $O$ estresse provocado pelo aumento da temperatura resulta em grande perda de carbono para manutenção da respiração, e consequentemente o metabolismo de copostos fenólicos, especilamente a glicosilação dos flavonóides pode ser retardada (Kuokkanen et al., 2001).

Outro tipo de estresse que interfere na síntese de metabólitos secundários é o estresse hídrico. Tongma e colaboradores (2001), demostraram que extratos de Tithonia diversifolia cultivadas em solos com diferentes níveis de umidade, apresentaram variação na atividade alelopática para arroz (Oryza sativa). A atividade alelopática foi maior quanto menor o nível 
de umidade do solo no qual a $T$. diversifolia foi cultivada. Comprovaram, assim, que em condições de estresse hídrico ocorre maior acúmulo de compostos alelopáticos, apesar da redução no crescimento e incorporação de biomassa desta espécie.

\subsubsection{Influência da Variação Sazonal}

O clima exerce uma influência direta sobre a vegetação, assim como uma influência indireta, via solo. As informações obtidas dos diversos estudos fitoquímicos realizados sugerem que a biossíntese e o acúmulo de metabólitos secundários é suscetível à variação sazonal, geográfica e talvez até circadiana, apesar de esta hipótese não ter sido ainda confirmada devido à escassez de trabalhos que enfoquem esses parâmetros (Taiz \& Zeiger, 1998).

A variação sazonal consiste em um conjunto de fatores que alteram o metabolismo vegetal. Por exemplo, a variação na temperatura durante o ano provoca mudanças de rotas biossintéticas no vegetal, implicando em diferentes tipos e quantidades de certas substâncias. A principal alteração ocorre no metabolismo de ácidos graxos, especialmente daqueles que compõem a parede celular (Taiz \& Zeiger, 1998).

Em geral, as espécies apresentam épocas específicas em que contêm maior quantidade de princípios ativos no seu tecido, podendo esta variação ocorrer tanto no período de um dia, como em épocas do ano (Simões et al., 1999).

Clement e colaboradores (1997) identificaram que em amostras de Acacia berlandieri coletadas no outono continham maiores quantidades de aminas e alcalóides, quando comparadas com as amostras coletadas no começo da primavera.

Um experimento testando a variação sazonal da produção de terpenos, ácidos de resina e fenóis em Pinus sylvestris L., concluiu que concentração de terpenos foi dependente da época de amostragem, ou seja, houve maior 
quantidade de $\alpha$ - pineno e outros monoterpenos e menos mirceno e tricicleno na primavera do que no outono. Quanto aos ácidos de resina (abiético, neoabiético e ácidos dehidroabiéticos), e os fenóis constatou-se uma maior concentração na Primavera do que no Outono (Nerg et al., 1994).

Para espécies como a Virola surinamensis a produção do óleo essencial apresentou-se constante durante as estações do ano e também ao longo do dia. Entretanto, houve variação na sua composição, que teve uma maior proporção de sesquiterpenos no inverno. E, no verão a quantidade de monoterpenos aumentou 50\%, indicando a importância de compostos voláteis no período de floração (Lopes et al., 1997).

Southwell \& Bourke (2001) monitoraram a síntese de hipericina pelo Hypericum perfloratum $L$. e determinaram que durante o outono e inverno os níveis desta substância atingiram quase zero, porém com o início da primavera a concentração sofreu um aumento rápido chegando ao máximo no começo do verão.

A concentração e a emissão de terpenos foi influenciada pela sazonalidade combinada com a variação de temperatura e a idade das plantas de Rosmarinus officinalis (Peñuelas \& Llusiá, 1997).

No entanto, para a espécie Tithonia diversifolia, ainda não existem relatos científicos da influência da sazonalidade na produção dos seus compostos ativos. 


\section{MATERIAL E MÉTODOS}

\subsection{Obtenção do material vegetal}

A espécie Tithonia diversifolia (Hemsl) Gray foi identificada e sua excicata de $n^{\circ} 83969$ (Figura 2) encontra-se depositada no Herbário ESA do Departamento de Botânica da ESALQ - USP.

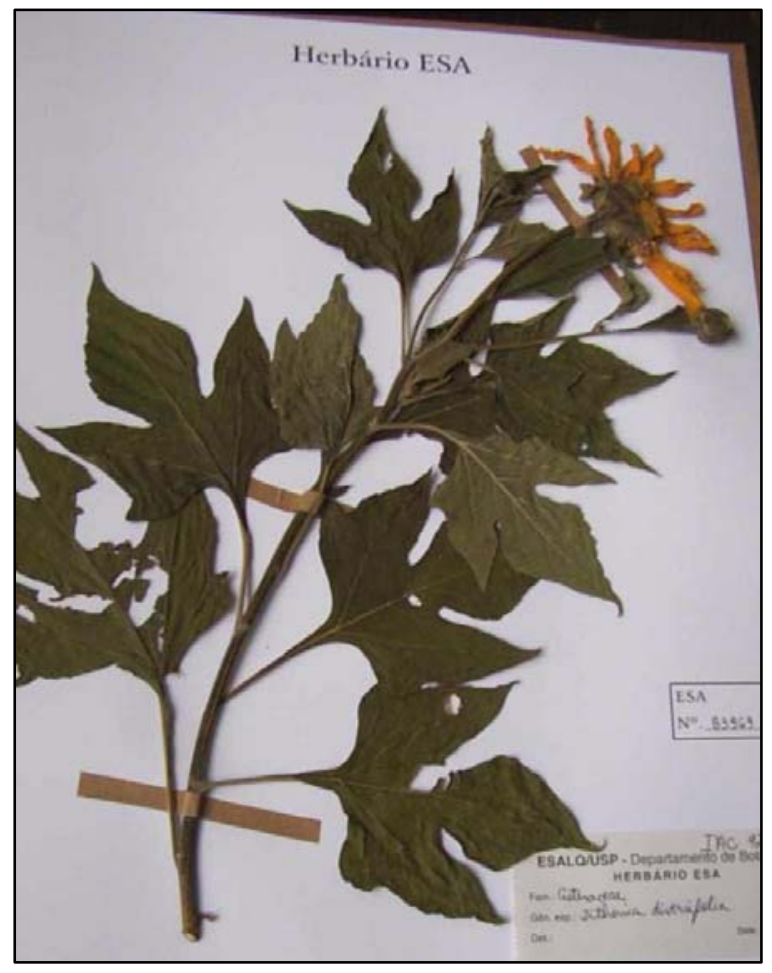

Figura 2 - Excicata da espécie Tithonia diversifolia (Hemsl) Gray 
As plantas cultivadas a partir de estacas foram mantidas em casa da vegetação do Horto Experimental do Departamento de Ciências Biológicas da ESALQ/USP (Figura 3), durante o período do experimento até as respectivas coletas ao longo do ano. Foram coletadas somente as folhas saudáveis e inteiras nos quatro períodos estabelecidos (Dezembro, Fevereiro Abril e Junho). No mês da florada (Junho) foram coletadas também as flores totalmente abertas.

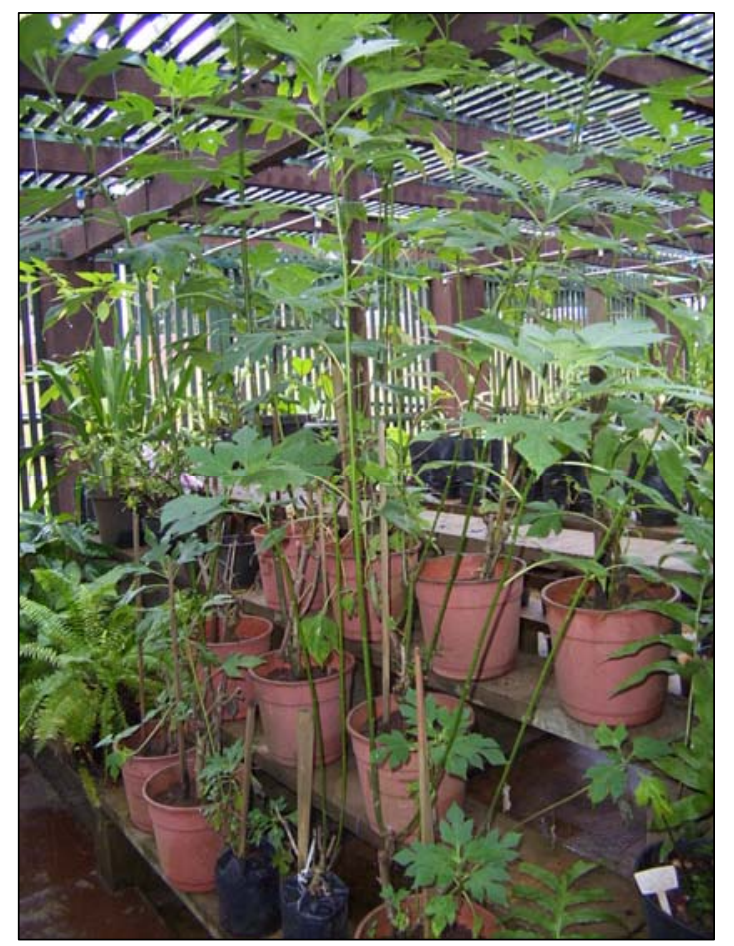

Figura 3 - Plantas em casa de vegetação, ESALQ/USP

Após a coleta foi feita a secagem em bancadas com telas, à sombra, em ambiente ventilado. Em seguida, o material foi triturado e moído em moinho Model $n^{\circ} 3$ fabricado pela Wiley Mill Standard - USA, para realizar o processo extrativo. 


\subsection{Metodologia aplicada ao estudo fitoquímico}

\subsubsection{Preparação dos extratos metanólicos de T. diversifolia}

As extrações foram feitas em dispersor do tipo Politron, onde $50 \mathrm{~g}$ do material vegetal seco foi extraído com $300 \mathrm{~mL}$ de metanol durante um minuto, seguido de filtração à vácuo dos extratos brutos. O procedimento foi repetido e os extratos agrupados e evaporados à vácuo em evaporador rotativo, mantendo a temperatura entre 40 e $45^{\circ} \mathrm{C}$, obtendo-se os extratos brutos secos. Foram reservados $10 \mathrm{~mL}$ dos extratos para monitoramento em CCD (Cromatografia em Camada Delgada), sendo o restante concentrado para determinação do rendimento.

A Figura 4 representa o fluxograma das extrações, o qual foi utilizado para realizar a metodologia nas épocas de coleta do material vegetal e posterior processamento para obtenção dos extratos metanólicos brutos (EMB).

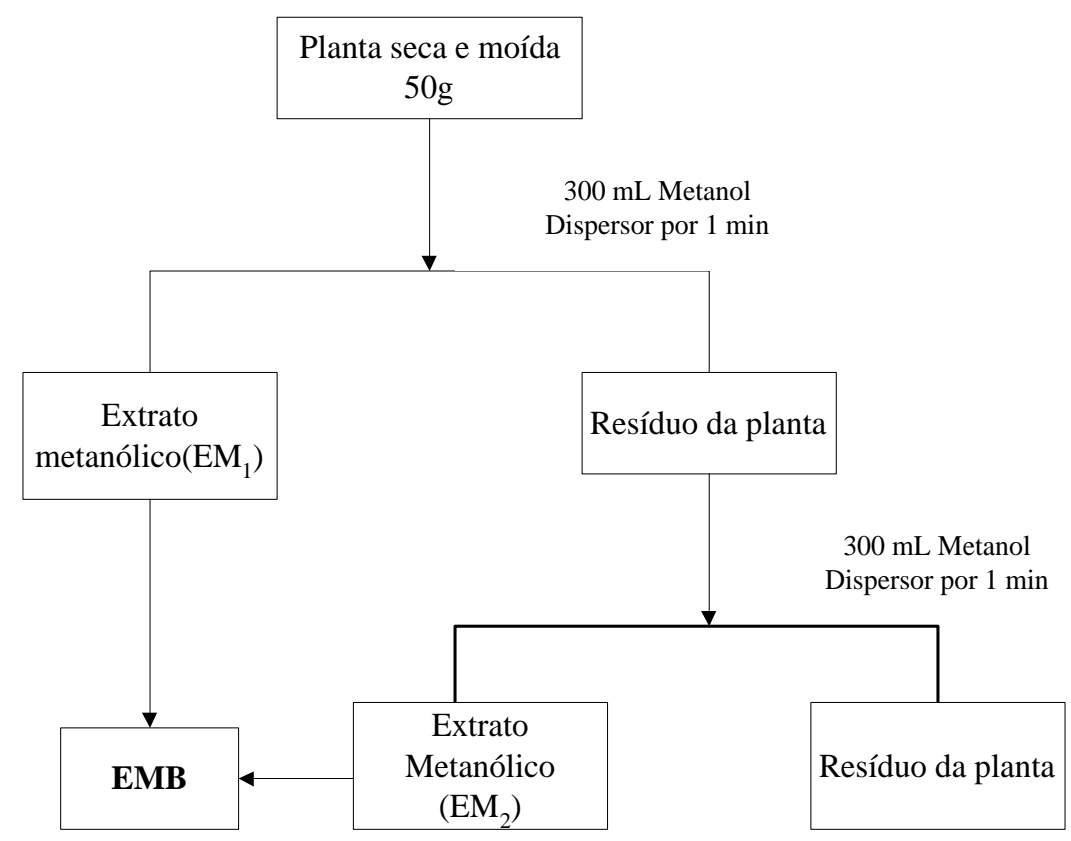

Figura 4 - Fluxograma das Extrações de Tithonia diversifolia 


\subsubsection{Fracionamento dos extratos metanólicos}

Os extratos metanólicos de $T$. diversifolia foram fracionados em coluna seca (Figura 5), utilizando membrana de celulose $(\varnothing=2 \mathrm{~cm}, 50 \mathrm{~cm}$ de altura) As colunas foram empacotadas com sílica gel 60 Merck (70-230 Mesh) e eluídas com Hexano:Acetato de Etila 1:1. O eluente foi definido após análises por CCD.

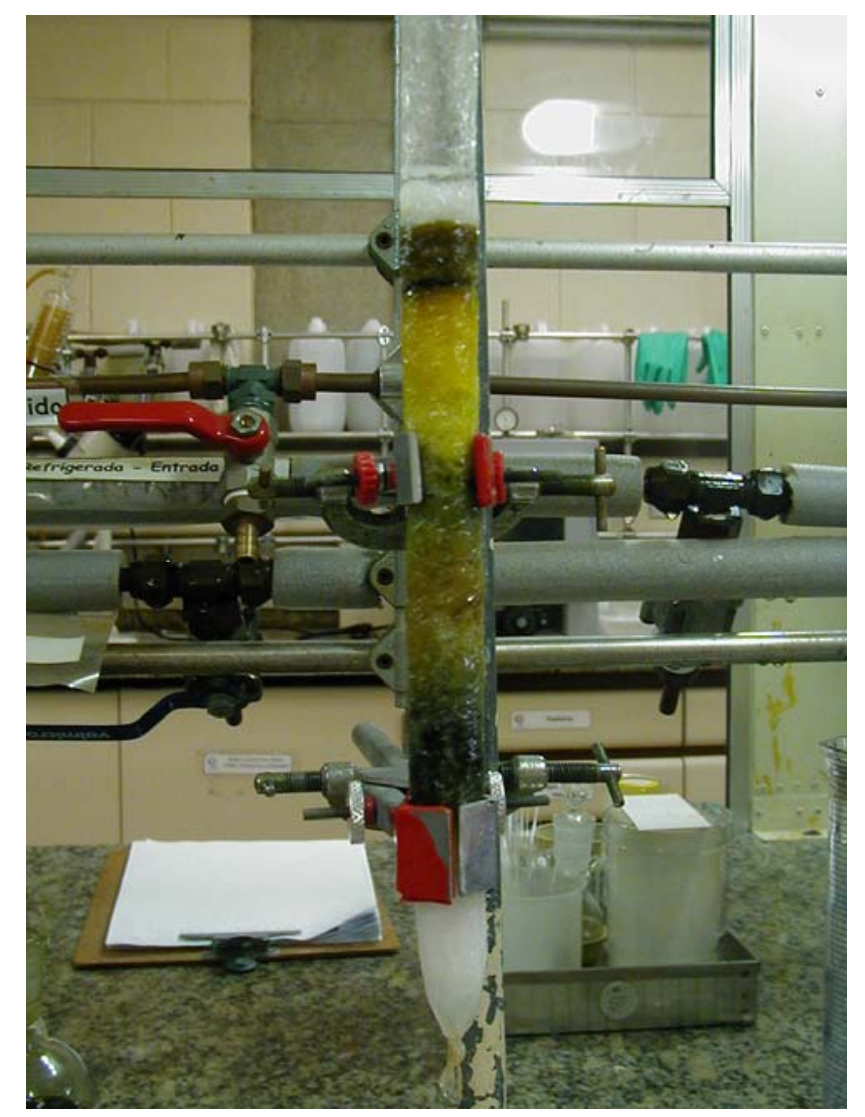

Figura 5 - Fracionamento do extrato bruto em coluna seca

Após eluição, as colunas foram divididas em seis partes de $8 \mathrm{~cm}$ cada, denominas de 1 a 5, além da papa (Figura 6). As frações foram extraídas com Acetato de Etila, filtradas a vácuo em funil de placa porosa, evaporadas à vácuo e analisada em CCD (Figura 7). 


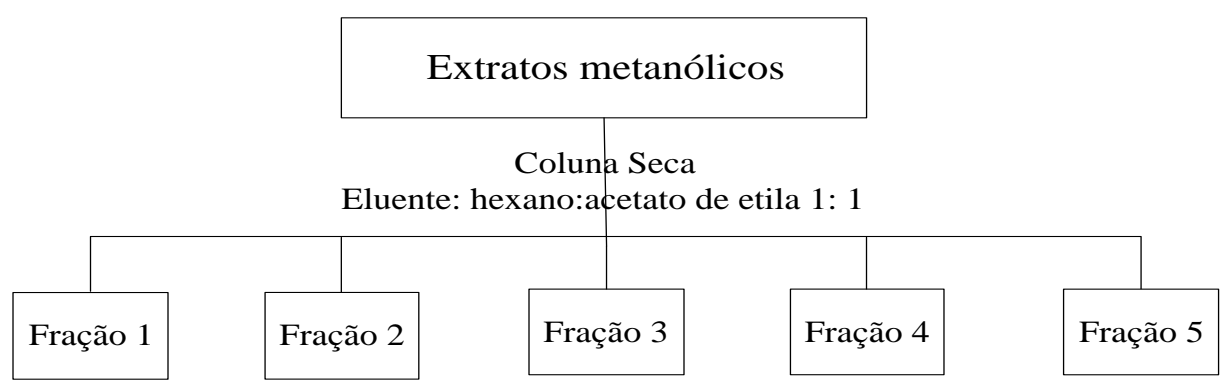

Figura 6 - Fluxograma de fracionamento dos extratos metanólicos

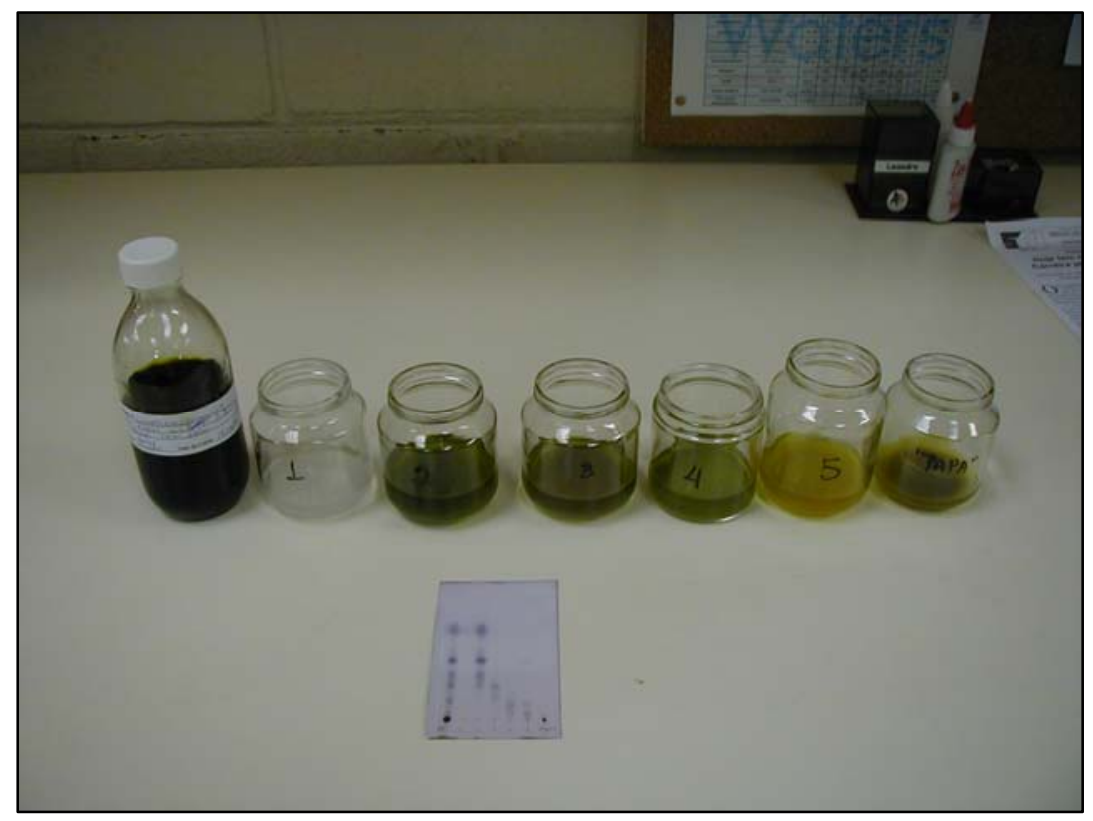

Figura 7 - Representação do extrato bruto e das frações

Esses procedimentos foram realizados no Laboratório de Bioquímica de Plantas do Centro de Biotecnologia (CEBTEC) da Esalq - USP.

\subsubsection{Análise cromatográfica (CCD) dos extratos e frações}


Todos os extratos e frações foram analisados através do método de CCD. Utilizou-se cromatoplacas de alumínio (Merck - artigo 5554). Os eluentes utiilizados foram Diclorometano:metanol (0,5\%), Diclorometano : metanol 2\%, Hexano : Acetato de etila 80:20 e Hexano : Acetato 1:1. Este último apresentou melhor separação dos compostos na placa cromatográfica, sendo escolhido para a realização do fracionamento dos extratos.

A detecção dos compostos foi feita por irradiação com lâmpada Ultravioleta-UV a 254 e 366 nm, seguida de pulverização com solução do revelador anisaldeído (ácido acético:ácido sulfúrico:anisaldeído 50:1,0:0,5 v/v) e aquecido em estufa a $100^{\circ} \mathrm{C}$ por 5 minutos.

Essas etapas foram realizadas na Divisão de Química Orgânica e Farmacêutica do Centro de Pesquisa Pluridisciplinar de Química, Biologia e Agronomia -CPQBA da UNICAMP, Campinas - SP.

\subsection{Metodologia aplicada ao estudo fisiológico}

\subsubsection{Variação sazonal de compostos secundários}

A fim de verificar a variação sazonal dos compostos ativos desta espécie, foram coletadas amostras durante as quatro estações do ano. Para isso estabeleceu-se quatro meses de um ano (Dezembro, Fevereiro, Abril e Junho) para coletar o material vegetal.

\subsection{Metodologia aplicada nos bioensaios}

\subsubsection{Microrganismos}

Foram utilizadas quatro espécies de microrganismos, uma nãopatogênica Escherichia coli, e três patogênicas Staphylococcus aureus, 
Salmonella choterasuis, Pseudomonas aeruginosa, causadoras de doenças em humanos.

A E. Coli participa da constituição da flora intestinal dos seres humanos, e apesar de não causar danos aparentes, pode desencadear reações inflamatórias, como por exemplo nas vias urinárias e septicemia, quando fora de seu habitat natural (Murray,1998).

A maioria dos distúrbios gastrointestinais é causado pela Salmonella choterasuis, que está presente em alimentos contaminados. Pode causar também septicemia (Murray,1998).

O Staphylococcus aureus e a Pseudomonas aeruginosa, são os principais microrganismos causadores das infecções hospitalares, além de causarem inúmeras infecções desde infecções de pele até pneumonias e endocardite (Murray,1998).

\subsubsection{Meio de cultura e metodologia}

O meio de cultuta utilizado é composto de Ágar Mueller-Hinton (Merck) para manutenção das linhagens, contendo (g/L): infusão de carne, 2,0; hidrolisado de caseína, 17,5; amido, 1,5, agar-agar, 15,0. Caldo Mueller-Hinton para testes de atividade antimicrobiana, conforme composição acima, sem agar-agar.

Em uma microplaca esterilizada de 96 orifícios ou poços, foram depositados $100 \mu \mathrm{L}$ de caldo Mueller-Hinton, com exceção da coluna 12, que foi utilizada para os controles. Na coluna 1 - linha A foram acrescentados $50 \mu \mathrm{L}$ do extrato testado, de concentração conhecida. Em seguida, $100 \mu \mathrm{L}$ do conteúdo do orifício foram homogeneizados com o meio e transferidos para o orifício da linha seguinte $(B)$, repetindo-se este procedimento até a linha $\mathrm{H}$, de modo a obter uma concentração decrescente do extrato. Os $100 \mu \mathrm{L}$ finais foram desprezados. Em seguida, $100 \mu \mathrm{L}$ de uma suspensão da bactéria $E$. coli de 
crescimento recente (24 horas), cuja turvação foi comparada à escala de McFarland $n^{0} 0,5$ e diluídos para concentração final de $10^{4}$ células por $\mathrm{mL}$ serão adicionados. As placas foram seladas com parafilm e incubadas por $24 \mathrm{~h}$ à $37^{\circ} \mathrm{C}$. Após este período foi acrescentado $20 \mu \mathrm{L}$ de uma solução aquosa de TTC (cloreto de trifenil tetrazolium) à 0,5\%, e a placa foi re-incubada por $3 \mathrm{~h}$ na referida temperatura. A CIM foi definida como a menor concentração do extrato capaz de impedir o aparecimento de coloração vermelha. 


\section{RESULTADOS E DISCUSSÃO}

\subsection{Rendimento dos extratos}

Os rendimentos dos extratos e frações obtidos da espécie Tithonia diversifolia nas quatro épocas do ano estão representados na Tabela 1.

Tabela 1. Rendimento dos extratos metanólicos de T. diversifolia

\begin{tabular}{lcccccc}
\hline \multicolumn{1}{c}{ Mês } & \multicolumn{7}{c}{ Peso (g) } \\
& EMB & F1 & F2 & F3 & F4 & F5 \\
\hline Dezembro & 1,42 & 0,12 & 0,18 & 0,30 & 0,19 & 0,20 \\
Fevereiro & 4,30 & 0,10 & 0,20 & 0,30 & 0,30 & 0,10 \\
Abril & 3,90 & 0,20 & 0,10 & 1,0 & 0,20 & 0,30 \\
Junho & 5,70 & 0,20 & 0,61 & 1,10 & 0,45 & 0,62 \\
Flores (junho) & 7,70 & 0,40 & 0,55 & 2,20 & 0,90 & 0,20 \\
\hline
\end{tabular}

Durante as diferentes estações do ano ocorre uma variação no rendimento dos extratos metanólicos brutos, bem como entre as frações de cada um deles.

\subsection{Análise dos extratos por CCD}

Os extratos metanólicos obtidos nas diferentes épocas e ano e suas respectivas frações foram analisadas por CCD em eluente composto de Hexano:Acetato de Etila 1:1 para visualização dos componentes da mistura. 
Nas figuras 8 e 9 estão apresentadas as placas dos extratos metanólicos sem revelador e com revelador (solução de anisaldeído), respectivamente.

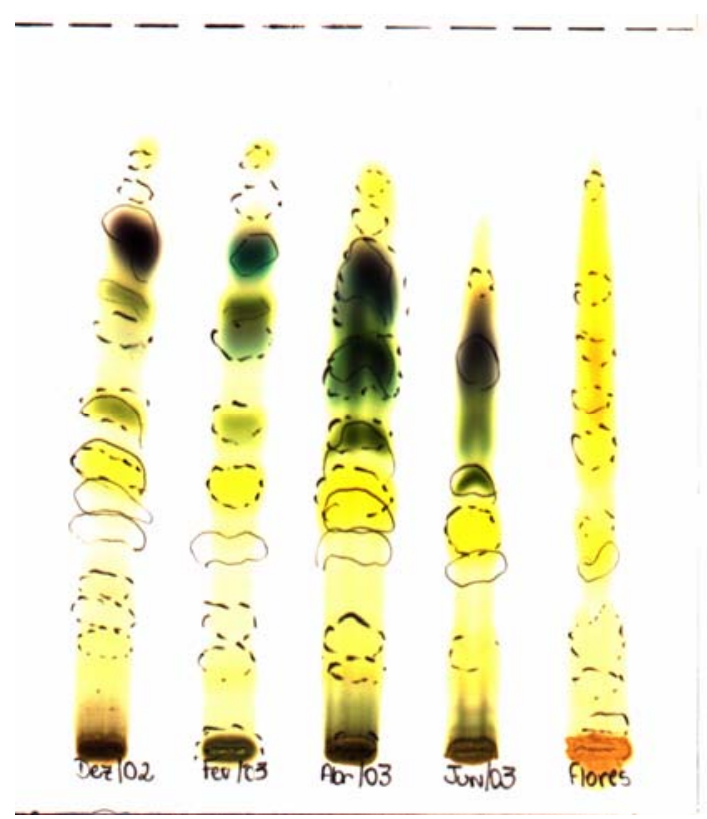

Figura 8 - Placa cromatográfica dos extratos metanólicos

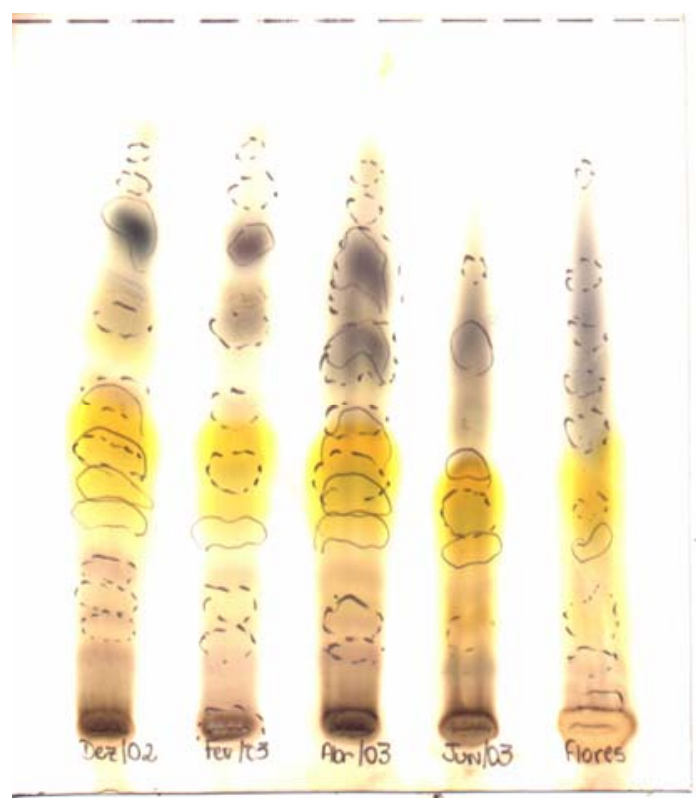

Figura 9 - Placa cromatográfica dos extratos metanólicos revelada com solução de anisaldeído 
Nas placas cromatográficas observa-se a presença de um determinado grupo de substâncias nos perfis cromatográficos dos meses de fevereiro e abril, sendo neste último com maior intensidade. Entretanto, no mês de junho a mancha correspondente a tal grupo de substâncias desaparece. Isto propõe uma variação qualitativa na composição dos extratos metanólicos brutos de acordo com a época de coleta do material vegetal. Sugerindo também uma alteração na concentração de tais substâncias.

O conhecimento do momento correto de coleta do material desejado leva à obtenção de produtos de melhor qualidade. Geralmente, essa variação ocorre em função do estágio em que se encontra a planta, como plena floração ou no período em que antecede a floração (Simões et al., 1999).

De acordo com a literatura consultada, a maioria das espécies medicinais apresenta uma maior concentração de metabólitos secundários no período de pré-floração, com algumas excessões.

Para esta espécie evidênciou-se perfis cromatográficos distintos para o período de pré-floração e floração. Surge assim, a hipótese de uma composição diferente entre tais extratos, com possível variação na concentração dos seus componentes. No entanto, para se obter tal informação é necessária a continuidade do processo de fracionamento e isolamento para se obter a composição exata de cada extrato, a fim de quantificar cada componente. E assim, estabelecer com maior precisão a porcentagem de aumento na produção de cada um deles no decorrer do ano.

\subsection{Avaliação da atividade antimicrobiana}

A Tabela 2 mostra os valores obtidos para CIM dos extratos metanólicos da $T$. diversifolia, que apresentou variações de acordo com a estação do ano e a fração testada. 
Tabela 2. Valores da Concentração Inibitória Mínima (CIM-mg mL ${ }^{-1}$ )

\begin{tabular}{|c|c|c|c|c|c|}
\hline \multirow[t]{2}{*}{ Amostra } & \multirow{2}{*}{$\begin{array}{c}\text { Frações / } \\
\text { MB }\end{array}$} & \multicolumn{4}{|c|}{$\begin{array}{c}\mathrm{CIM} \\
\mathrm{mg} \mathrm{mL}^{-1}\end{array}$} \\
\hline & & Pseudomonas & E. coli & S. aureus & Salmonella \\
\hline \multirow{5}{*}{$\begin{array}{l}\text { Dez/02 } \\
\text { Folhas }\end{array}$} & F1 & $>1,0$ & $>1,0$ & $>1,0$ & $>1,0$ \\
\hline & F2 & $>1,0$ & $>1,0$ & 0,05 & 0,80 \\
\hline & F3 & $>1,0$ & $>1,0$ & 0,125 & 0,15 \\
\hline & F4 & $>1,0$ & $>1,0$ & 0,15 & 0,20 \\
\hline & EMB & $>1,0$ & $>1,0$ & 0,20 & 0,25 \\
\hline \multirow{6}{*}{$\begin{array}{l}\text { Fev/03 } \\
\text { Folhas }\end{array}$} & F1 & $>1,0$ & $>1,0$ & 0,125 & 0,10 \\
\hline & F2 & $>1,0$ & $>1,0$ & 0,04 & 0,06 \\
\hline & F3 & $>1,0$ & $>1,0$ & 0,02 & 0,13 \\
\hline & F4 & $>1,0$ & $>1,0$ & 1,0 & $>1,0$ \\
\hline & F5 & $>1,0$ & $>1,0$ & $>1,0$ & $>1,0$ \\
\hline & EMB & $>1,0$ & $>1,0$ & 0,50 & 0,60 \\
\hline \multirow{6}{*}{$\begin{array}{l}\text { Abr/03 } \\
\text { Folhas }\end{array}$} & F1 & $>1,0$ & $>1,0$ & 0,40 & 0,40 \\
\hline & F2 & $>1,0$ & $>1,0$ & 0,10 & 0,125 \\
\hline & F3 & $>1,0$ & $>1,0$ & 0,10 & 0,04 \\
\hline & F4 & $>1,0$ & $>1,0$ & $>1,0$ & $>1,0$ \\
\hline & F5 & $>1,0$ & $>1,0$ & $>1,0$ & $>1,0$ \\
\hline & EMB & $>1,0$ & $>1,0$ & 0,125 & 0,08 \\
\hline \multirow{5}{*}{$\begin{array}{l}\text { Jun/03 } \\
\text { Folhas }\end{array}$} & F2 & $>1,0$ & $>1,0$ & 0,125 & 0,13 \\
\hline & F3 & $>1,0$ & $>1,0$ & 0,03 & 0,05 \\
\hline & F4 & $>1,0$ & $>1,0$ & 0,125 & 0,1 \\
\hline & F5 & $>1,0$ & $>1,0$ & $>1,0$ & $>1,0$ \\
\hline & EMB & $>1,0$ & $>1,0$ & 0,20 & 0,25 \\
\hline \multirow{5}{*}{$\begin{array}{c}\text { Junho/03 } \\
\text { Flores }\end{array}$} & F1 & $>1,0$ & $>1,0$ & $>1,0$ & $>1,0$ \\
\hline & F2 & $>1,0$ & $>1,0$ & 0,40 & 0,50 \\
\hline & F3 & $>1,0$ & $>1,0$ & 0,20 & 0,25 \\
\hline & F4 & $>1,0$ & $>1,0$ & 0,30 & 0,40 \\
\hline & F5 & $>1,0$ & $>1,0$ & $>1,0$ & $>1,0$ \\
\hline
\end{tabular}

A atividade antimicrobiana apresentada pelos extratos metanólicos foi mais significativa para $S$. aureus e Salmonella choterasuis. O extrato metanólico das folhas coletadas no mês de Abril demonstrou menor concentração inibitória mínima (Figura 10), sugerindo uma maior concentração de compostos ativos neste extrato bruto. 


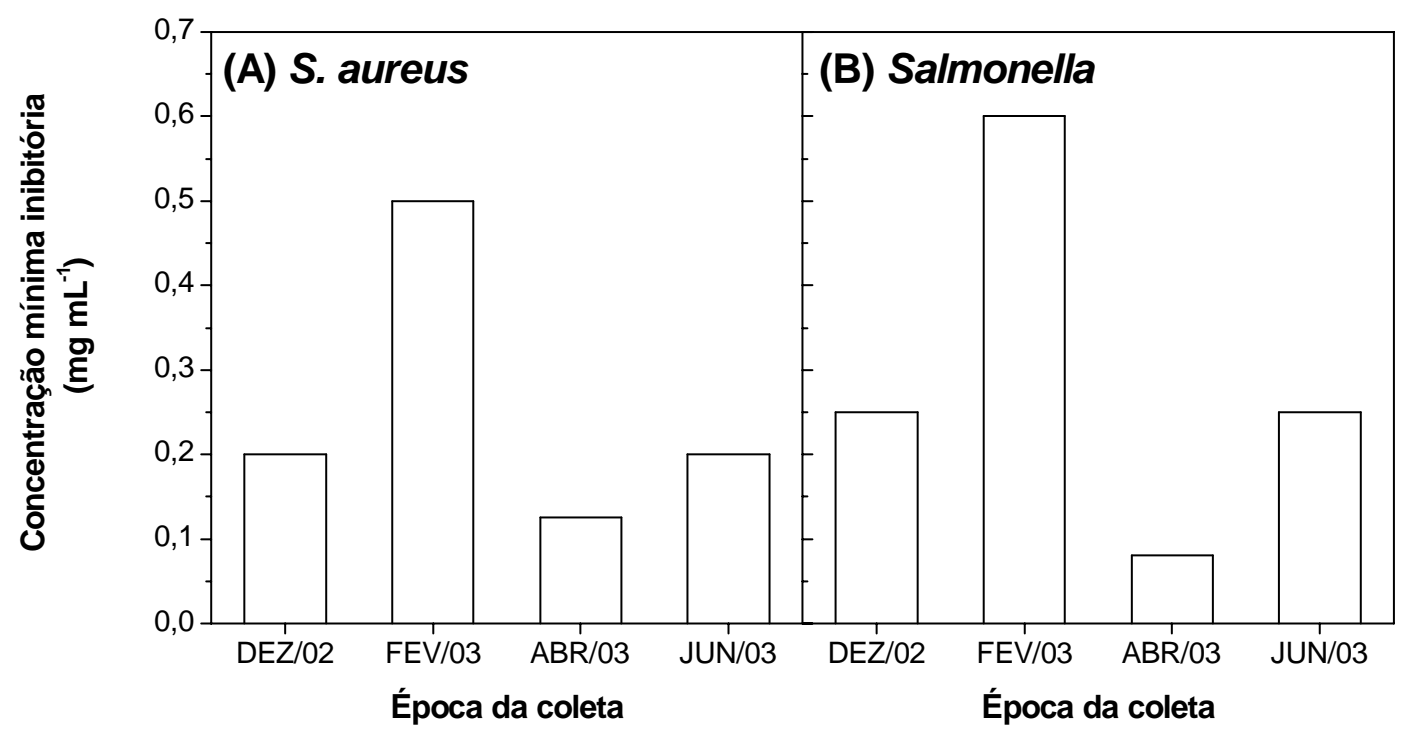

Figura 10 - CIM para os extratos brutos das folhas nas diferentes épocas de coleta

O padrão de inibição do crescimento bacteriano foi semelhante para as duas espécies testadas, sendo o extrato do mês de Abril o mais eficaz para ambos, e o extrato de mês de Fevereiro o menos eficiente.

Dentre todas as frações, as que tiveram menor CIM foram as F2 e F3 de todos os meses. Isto indica uma maior concentração de compostos ativos nas mesmas, ou ainda a presença de compostos ativos apenas nestas frações. Sendo que a fração F3 do mês de fevereiro apresentou a menor CIM dentre todas as frações e extratos testados. 


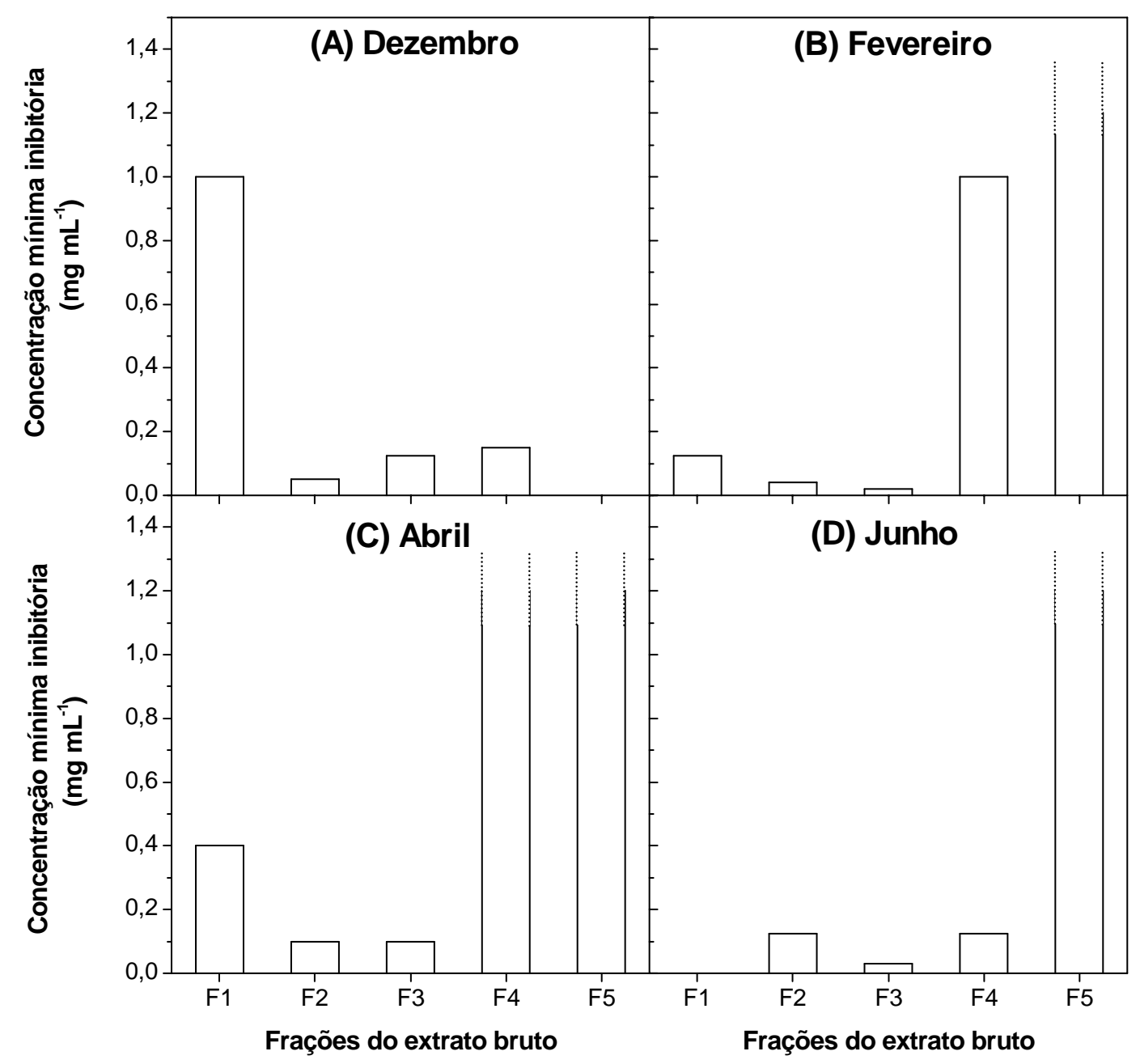

Figura 11 - Atividade antimicrobiana contra S. aureus das frações obtidas dos extratos metanólicos nas diferentes épocas de coleta

$\mathrm{Na}$ Figura 11, observa-se que, para $S$. aureus as frações $\mathrm{F} 2$ de dezembro e fevereiro, e ainda as frações F3 de fevereiro e de junho foram as mais ativas, com as menores CIM.

As frações F2 de fevereiro e F3 de abril foram mais ativas para Salmonella choterasuis, com CIM de 0,06 e $0,05 \mathrm{mg} \mathrm{mL}^{-1}$ respectivamente, como mostra a Figura 12. 


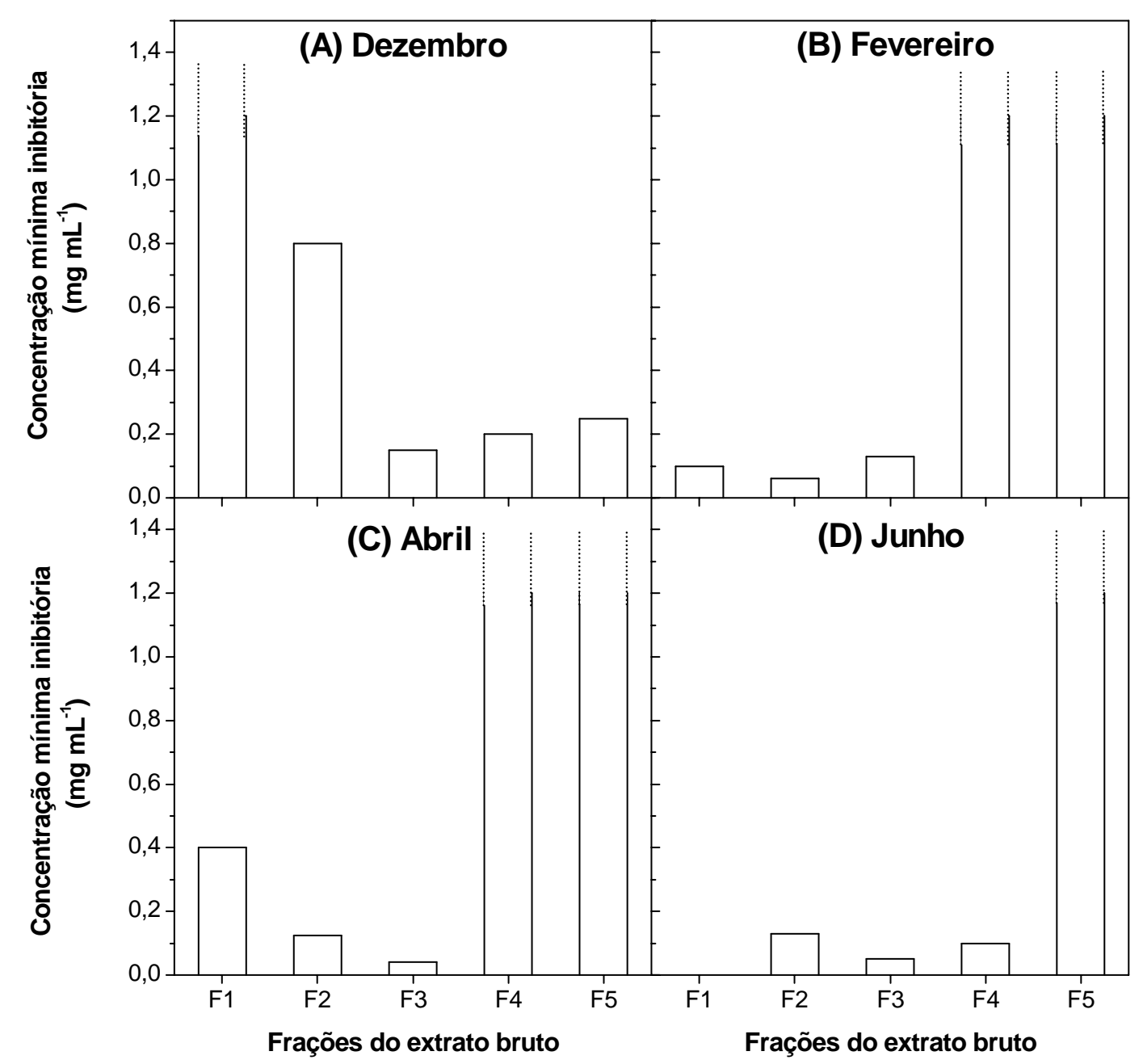

Figura 12 - Atividade antimocrobiana para Salmonella das frações obtidas dos extratos metanólicos brutos nas diferentes épocas de coleta

As frações que apresentam histogramas pontilhados correspondem aos valores de CIM maiores que $1 \mathrm{mg} \mathrm{mL}^{-1}$. Este valor é considerado inviável e não representativo para os testes realizados.

O extrato metanólico obtido com as flores da $T$. diversifolia apresentou atividade para os dois microorganismos $S$. aureus e Salmonella, sendo que a fração F3 foi a mais ativa para ambos (Figura 13). 


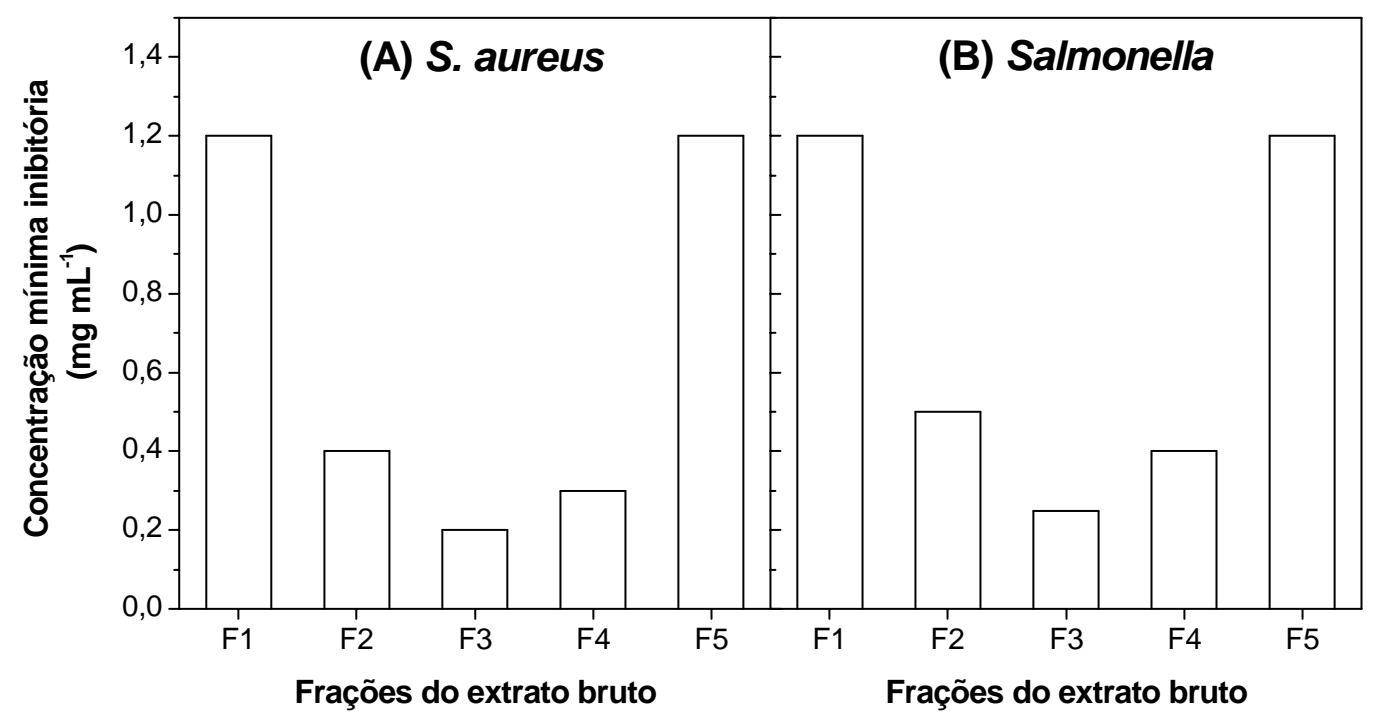

Figura 13 - Atividade antimicrobiana para S. aureus e Salmonella das frações obtidas a partir do extrato bruto das flores

Para os outros dois microrganismos testados, $P$. aeruginosa e E. coli, todos os extratos metanólicos apresentaram CIM não-significativa $\left(>1 \mathrm{mg} \mathrm{mL}^{-1}\right)$, sendo assim, foram considerados inativos contra tais espécies.

Estudos da literatura mostram que diferentes substâncias como óleos essenciais, extratos hidroalcoólicos ou metanólicos, dentre outros, não têm sido efetivos contra a bactéria $E$. coli, ou apresentaram inibição a concentrações superiores a 2,0 $\mathrm{mg} \mathrm{mL}^{-1}$. Dentre os extratos etanólicos de 12 plantas selecionadas por Silva et al. (1996), apenas um apresentou CIM de 1,56 $\mathrm{mg} \mathrm{mL}^{-1}$, enquanto os outros apresentaram CIM entre 6,25 e $25 \mathrm{mg} \mathrm{mL}^{-1}$, ou superior a $25 \mathrm{mg} \mathrm{mL}^{-1}$ para E. coli ATCC 25922. Diferentes frações etanólicas obtidas a partir da raiz Terminalia macroptera, testadas por este autor contra a mesma cepa, apresentaram CIM igual ou superior a $10 \mathrm{mg} \mathrm{mL}^{-1}$ (Silva et al., 1997). 
Extratos metanólicos brutos obtidos a partir de 12 plantas medicinais, testados por Navarro et al. (1996), apresentaram CIM de no mínimo $10 \mathrm{mg} \mathrm{mL}^{-1}$ contra E. coli ATCC 8937.

Nenhuma atividade antimicrobiana contra a bactéria $E$. coli foi observada nos trabalhos de Veràstegui et al. (1996), Cobos et al. (2001), Lopes et al. (2001) e Candan et al. (2003), que estudaram, respectivamente a ação de extratos etanólicos de plantas do deserto de Chihuahuan, óleos essenciais de Baccharis notosergila, extratos metanólicos de 24 plantas colombianas, e extratos de Achillea millefolium.

Têm-se constatado a mesma dificuldade em se encontrar substâncias naturais ativas contra a bactéria Pseudomonas aeruginosa. 


\section{CONCLUSÕES}

A atividade antibacteriana dos extratos metanólicos das folhas de $T$. diversifolia foi comprovada para apenas dois dos quatro microrganismos testados, sendo eles S. aureus e Salmonella choterasuis. As CIM foram satisfatórias e apresentaram variações relativas a época de coleta do material vegetal, onde o extrato bruto do mês do abril (pré-florada) mostrou-se mais efetivo nos testes.

Detectou-se, com esses resultados, a variação sazonal na produção de compostos ativos, embora haja a necessidade de continuidade da pesquisa a fim de determinar o(s) princípio(s) ativo(s) responsável(is) pela atividade antibacteriana e determinar sua(s) estrutura(s) química(s). 


\section{REFERÊNCIAS BIBLIOGRÁFICAS}

AKINOLA, J.O.; LARBI, A.; FARINU, G.O.; ODUNSI, A.A. Seed treatment methods and duration effects on germination of wild sunflower. Experimental Agriculture, v. 36, p.63-69, 2000.

AZCON-BIETO, J.; TALON, M. Fisiología y bioquímica vegetal. Madrid: Interamericana; McGraw-Hill, 1996. 581p.

BARUAH, N.C.; SARMA, J.C.; BARUA, N.C.; SARMA, S.; SHARMA, R.P. Germination and growth sesquiterpene lactones and a flavone from Tithonia diversifolia. Phytochemistry, v.36, p.29-36, 1994.

BOHLMANN, F.; ZDERO, C. Systematics and evolution within the Compositae seen with eyes of a chemist. Plant Systematic and Evolution, v.171, p.114, 1990.

BORDOLOI, M.; BARUA, N.C.; GHOSH, A.C. An artemisinic acid analogue from Thitonia Diversifolia. Phytochemistry, v.41, p.557-559, 1996.

CÁCERES, V.C. Efectos nutricionales sobre la callidad de la cáscara. In: CONFERÊNCIA APINCO DE CIENCIA E TECNOLOGÍA AVÍCOLAS, Santos, 1994. Anais. Santos: FACTA, 1994, p.35-66.

CANDAN, F.; UNLU, M.; TEPE, B.; DAFERERA, D.; POLISSIOU, M.; SÖKMEN, A.; AKPULAT, H. A. Antioxidant and antimicrobial activity of the essential oil and methanol extracts of Achillea millefolium subsp. Millefolium Afan. (Asteraceae). Journal of Ethnopharmacology, v.87, p.215-220, 2003.

CLEMENT, B.A.; GOFF, C. M.; FORBEST, D. A. Toxic amines and alkaloids from Acacia Berlandieri. Phytochemistry, v.46, p.249-254, 1997. 
COBOS, M.; RODRIGUEZ, J.L.; OLIVA, M.M.; DEMO, M.; FAILLACI, S.M.; YGADLO, J.A. Composition and antimicrobial activity of essential oil of Baccharis notosergila. Planta Medica, v.67, p.84-86, 2001.

DUTTA, P.; BHATTACHARYYA, P.R.; RABHA, L.C.; BORDOLOI, D.N.; BARUA, N.C.; CHOWDHURY, P.K.; SHARMA, R.P.; BARUA, J.N. Feeding deterrentes for Philosamia ricini (Samia Cynthia Subsp. Ricini) from Tithonia diversifolia. Phytoparasitica, v.14, p. 77-80, 1986.

ELOFF, J.N.P. A sensitive and quick microplate method to determine the minimal inhibitory concentration of plant extracts for bacteria. Planta Medica v.64, p.711-713, 1998.

GACHENGO, C.N.; PALM, C.A.; JAMA, B.; OTHIENO, C. Tithonia and senna green manures and inorganic fertilizers as phosphorus for maize in Western Kenya. Agroforestry Systems, v. 4, p.37-68, 1999.

HEYWOOD, V.; HARBORNE, J.B.; TURNER, B.L. The biology and chemistry of Compositae. London: Academic Press, 1977, 2 v.

JAMA, B.; PALM, C.A.; BURESH, R.J.; NIANG, A.; GASHENGO, C.; NZIGUHEBA, G.; AMADALO, B. Tithonia diversifolia as a green manure for soil fertility improvement in Western Kenya: a review. Agroforestry Systems, v.49, p.201-201, 2000.

KATTO, C.I.R.; SALAZAR, A. Botón de oro (Tithonia diversifolia (HemsI.) Gray) una fuente proteica alternativa para el trópico. Liverstock Research For Rural Development, v.6, 1-15, 1995.

KUOKKANEN, K.; TIITTO, R. J.; KEINÄNEN, M.; PEKKA, N.; TAHVANAINE, J. The effect of elevated $\mathrm{CO}_{2}$ and temperature on the secondary chemistry of Betula pendula seedlings. Trees-Structure and Function, v.15, p.378384. 2001.

LOPEZ, N.P.; KATO, M.J.; ANDRADE, E.H.A.; MAIA, J.G.S.; YOSHIDA, M. Circadian and seasonal variation in the essencial oil from Virola surinamensis leaves. Phytochemistry, v.46, p.689-693, 1997. 
LOPEZ, A.; HUDSON, J.B.; TOWERS, G.H.N. Antiviral and antimicrobial activities of Colombian medicinal plants. Journal of Ethnopharmacology. v.77, p.189-196, 2001.

MACÍAS, F.; GALINDO, J. C.; MASSNET, G. M. Potencial allelopathic activity of several sesquiterpene lactones models. Phytochemistry, v.32, p.383-385, 1992.

MEDINA, M.L.B.; CARREÑO, R. J. D. Evaluation del material foliar de rayo de sol comoposible fuente de xantofilas. Agronomía Tropical, v.49, p. 373390, 1999.

MURRAY, P.; ROSENTHAL, S. Microbiologia médica. $3^{\text {a }}$ ed. LOCAL :Ed. Guanabara Koogan, 1998. III p.

NAVARRO, V.; VILLAREAL, M. L.; ROJAS, G.; LOZOYA, X. Antimicrobial evaluation of some plants used in Mexican traditional medicine for the treatment of infectious diseases. Journal of Ethnopharmacology, v.53, p.143-147, 1996.

NERG, A.; KAINULAINEN P.; VUORINE, M.; HANSO, M.; HOLOPAINEN, J.K.; KURKELA, T. Seasonal and geographical variation of terpenes, resin acids and total phenolics in nursery grown seedlings of Scots pine (Pinus sylvestris L.). New Phytologist, v.128, p.703-713, 1994.

ODUNSI, A.A.; FARINU, G. O.; AKINOLA, J.O. Influence of dietary wild sunflower (Tithonia diversifolia Hemsl Gray) leaf meal on layers performance and egg quality. Nigerian Journal of Animal Production, v.23, p.28-32, 1996.

OWOYEle, V.B. WURAOlA, C.O., SOlAdOYE, A. O., OlAleye, S. B. Studies on the anti-inflammatory and analgesic properties of Tithonia diversifolia leaf extract. Journal of Ethnopharmacology, v.90, p. 327-321, 2004.

PEÑUELAS, J.; LLUSIÁ, J. Effects of carbon dioxide, water supply and seasonality on terpene content and emmission by Rosmarinus officinalis. Journal of Chemical Ecology, v. 23, p.979-992, 1997. 
PICMAN, A. K. Biological activities os sesquiterpenes lactonas. Biochemistry Systems Ecology, v.14, p.255-281, 1986.

RODRIGUEZ, E.; TOWERS, G. H. N.; MITCHEL, J. C.. Biological activities of sesquiterpenes lactones. Phytochemistry, v.15, p.1573-1580, 1976.

RÜNGELER, P.; LYB, G., CASTRO, V.; MORA, G.; PAHL, H.; MERFORT, I.

Study of Three Sesquiterpenes Lactones from Tithonia diversifolia on their Anti-Inflammatory activity using the transcription factor NF-kB and enzymes of the arachidonic acid pathway as targets. Planta Medica, v.64, p.588593, 1998.

SEAMAN, F.C. Sesquiterpenes lactones taxonomic characters in Asteraceae.

Botanical Reviews, v.48, p.123-551, 1982.

SCHUSTER, A.; STOCKES, S.; PAPASTERGIOU, F.; CASTRO, V.; POVEDA, L.; JAKUPOVIC, J. Sesquiterpene lactones from two tithonia species. Phytochemistry, v.31, p.3139-3141, 1992.

SILVA, O.; DUARTE, A.; CABRITA, J.; PIMENTEL, M.; DINIZ, A.; GOMES, E. Antimicrobial activity of Guinea-Bissau traditional remedies. Journal of Ethnopharmacology, v.50, p. 55-59, 1996.

SILVA, O.; DUARTE, A.; PIMENTEL, M.; VEIGAS, S.; BARROSO, H.; MACHADO, J.; PIRES, I.; CABRITA, J.; GOMES, E. Antimicrobial activity of Terminalia macroptera root. Journal of Ethnopharmacology, v.57, p.203207, 1997.

SIMÕES, C. M. O.; SHENKEL, E. P.; GRACO, G.; MELLO, J. C. P.; MENTZ, L. A.; PETROVICK, P.R. Farmacognosia: da planta ao medicamento, Florianópolis: Editora da UFSC, 1999. 821p.

SOUTHWELL, I. A.; BOURKE, C. A. Seasonal variation in hypericin content of Hypericum perfloratum L. Phytochemistry, v. 56, p. 437-441, 2001.

TAIZ, L.; ZEIGER, E. Plant physiology. Massachusetts: Sinauer Associates, 1998. 793p. 
TONA, L.; KAMBU, K.; NGIMBI, N.; CIMANGA,K.; VLIETINCK, A.J. Antiamoebic and phytochemical screening of some Congolese medicinal plants. Journal of Pharmacology, v.61, p.57-65, 1998.

TONGMA, S.; KOBAYASHI, K.; USUI, K. Allelopathic activity of Mexican sunflower (Tithonia diversifolia) in soil. Weed Science, v.46, p.432-437, 1998.

TONGMA, S.; KOBAYASHI, K.; USUI, K. Allelopatic activity of Mexican sunflower [Tithonia diversifolia (Hemsl) A. Gray] in soil under natural field conditions and different moisture conditions. Weed Biology and Management, v.1, p.115-119, 2001.

VERÁSTEGUI, M.A.; SÁNCHEZ, C.A.; HEREDIA, N.L.; GARCÍA-ALVARADO, J.S. Antimicrobial activity of extracts of three major plants from the Chihuahuan desert. Journal of Ethnopharmacology, v.52, p.175-177, 1996.

WALLART, T.E.; PRAS, N.; BEEKMAN, A.C.; QUAX, W.J. Seasonal variation of artemisinin and its biossynthetic precursors in plants of Artemisia annua of different geographical origin: proof for the existance of chemotypes. Planta Medica, v.66, p.57-62, 2000. 